\title{
Celecoxib inhibits the epithelial-to-mesenchymal transition in bladder cancer via the miRNA-145/TGFBR2/Smad3 axis
}

\author{
XIAOQIANG LIU ${ }^{1,2^{*}}$, YANLONG WU $^{3 *}$, ZHENGTAO ZHOU $^{1}$, MINGCHUAN HUANG $^{1}$, \\ WEN DENG ${ }^{1}$, YIBING WANG ${ }^{4}$, XIAOCHEN ZHOU $^{1}$, LUYAO CHEN $^{1}$, YU LI $^{1}$, \\ TAO ZENG ${ }^{5}$, GONGXIAN WANG ${ }^{1,2}$ and BIN FU $^{1,2}$ \\ ${ }^{1}$ Department of Urology, The First Affiliated Hospital of Nanchang University; ${ }^{2}$ Jiangxi Institute of Urology; \\ ${ }^{3}$ Department of Gynaecology and Obstetrics, The People's Hospital of Jiangxi Province; ${ }^{4}$ Department of \\ Emergency, The Second Affiliated Hospital of Nanchang University; ${ }^{5}$ Department of Urology, \\ The People's Hospital of Jiangxi Province, Nanchang, Jiangxi 330006, P.R. China
}

Received March 1, 2019; Accepted June 7, 2019

DOI: $10.3892 / \mathrm{ijmm} .2019 .4241$

\begin{abstract}
Celecoxib, a selective cyclooxygenase-2 inhibitor, has chemo-preventive activity against different cancer types, including bladder cancer (BC). However, the mechanisms by which celecoxib exerts its cancer preventative effects have yet to be completely understood. In the present study, the effect of celecoxib on the epithelial-to-mesenchymal transition (EMT) of BC cells and its potential molecular mechanisms were investigated. The results of the present study demonstrated that celecoxib inhibited the proliferation, migration, invasion and EMT of BC cells. Further investigation of the underlying mechanism revealed that celecoxib inhibited EMT by upregulating microRNA (miR)-145 and downregulating the expression of transforming growth factor $\beta$ receptor 2 and SMAD family member 3 . Furthermore, the combination of celecoxib with miR-145 mimics demonstrated an additive migration and invasion-inhibitory effect in $\mathrm{BC}$ cell lines.
\end{abstract}

\section{Introduction}

Bladder cancer (BC) is the fourth most common cancer type in men in the United States and causes $\sim 150,000$ cases of mortality annually worldwide; therefore, it is increasingly becoming a pressing health problem $(1,2)$. Approximately $75 \%$ of cases are non-muscle-invasive BC (NMIBC; type Ta, T1), which are usually treated with the transurethral resection of the bladder tumor followed by intravesical chemotherapy (3).

Correspondence to: Professor Bin Fu, Department of Urology, The First Affiliated Hospital of Nanchang University, 17 Yongwaizheng Street, Nanchang, Jiangxi 330006, P.R. China

E-mail: urofubin@sina.com

*Contributed equally

Key words: celecoxib, bladder cancer, microRNA-145
Although patients with NMIBC have a high survival rate, unfortunately, $50 \%$ of these patients recur and $20 \%$ progress to muscle-invasive BC (4). Tumor types at high risk of recurrence and progression, therefore, require neoadjuvant treatment (5). In addition to chemotherapy, at present, intravesical bacillus Calmette-Guérin (BCG) immunotherapy is also used for these patients to prolong the time of recurrence and progression. Nevertheless, intravesical BCG immunotherapy is associated with a number of side effects. In addition to this, $30-80 \%$ of patients treated with this therapy still recur (6).

It has been reported that the expression of cyclooxygenase-2 $(\mathrm{COX}-2)$ is associated with a high tumor grade and stage in BC $(7,8)$. Celecoxib, a selective COX-2 inhibitor, was produced for pain relief and anti-inflammation, and is now also used for suppressing tumor proliferation and invasion. It has been also reported that celecoxib inhibits growth, induces apoptosis and reverses the epithelial-to-mesenchymal transition (EMT) of BC cells $(9,10)$. Furthermore, the combination of celecoxib with BCG is more effective compared with BCG alone in a model of urothelial cell carcinoma (11). However, the precise mechanisms of celecoxib in $\mathrm{BC}$ cells remains unknown.

MicroRNA (miRNA/miR) are a group of single-stranded noncoding small RNAs that participate in posttranscriptional gene regulation through inducing the degradation of target mRNAs by binding to the 3 ' untranslated region of mRNAs (12). Emerging evidence indicates that the dysregulation of miRNA expression contributes to tumor initiation, proliferation, invasion and metastasis (13). Celecoxib has been reported to reverse the EMT of BC cells $(9,10)$. However, the underlying molecular mechanisms by which celecoxib inhibits EMT in BC cells have not been identified. Whether celecoxib could inhibit EMT via regulating the expression of miRNAs in BC remains largely unknown. The present study aimed to investigate the role of celecoxib on cancer progression and miRNA expression in $\mathrm{BC}$.

Numerous studies have revealed that the combination of celecoxib with other agents may have synergistic anti-cancer effects in a number of different cancer types (14-16). To the best of our knowledge, no studies have previously reported the 
effect of the combination of celecoxib and miRNAs in BC. In the present study, the anticancer effect of celecoxib combined with miR-145 on the progression of $\mathrm{BC}$ was determined.

\section{Materials and methods}

Cell culture and treatment. Human BC cells of the 5637, J82 and T24 cell lines, and the SV-HUC-1 human immortalized uroepithelium cell line, were purchased from the Cell Bank of Type Culture Collection of the Chinese Academy of Sciences, Shanghai Institute of Cell Biology (Shanghai, China). 5637, J82 and T24 cells were maintained in RPMI-1640 (Gibco; Thermo Fisher Scientific, Inc., Waltham, MA, USA) and SV-HUC-1 cells were cultured in F-12K medium (Gibco; Thermo Fisher Scientific, Inc.). Media were supplemented with $10 \%$ heat-inactivated fetal bovine serum (FBS; Hyclone; GE Healthcare Life Sciences, Logan, UT, USA), 100 U/ml penicillin and $100 \mu \mathrm{g} / \mathrm{ml}$ streptomycin at $37^{\circ} \mathrm{C}$ in a humidified incubator with 5\% $\mathrm{CO}_{2}$. Cells of the 5637 and T24 cell line were exposed to 60 or $80 \mathrm{ng} / \mathrm{ml}$ celecoxib (PeproTech, Inc., Rocky Hill, NJ, USA) for $48 \mathrm{~h}$ at $37^{\circ} \mathrm{C}$ in an atmosphere containing $5 \% \mathrm{CO}_{2}$. Cells treated with dimethyl sulfoxide alone were used as controls.

Transfection. Cells of the 5637 and T24 cell line were plated in 6 -well plates at a density of $2 \times 10^{5}$ per well. The has-miR-145-5p inhibitor, mimic and negative control (NC) were obtained from Guangzhou RiboBio Co., Ltd. (Guangzhou, China). The sequence of miR-145-5p mimics and miR-145-5p inhibitors was 5'-GUCCAGUUUUCCCAGGAAUCCCUGGAUUCC UGGGAAAACUGGACUU-3' and 5'-AGGGAUUCCUGG GAAAACUGGAC-3', respectively, and that of the negative control was 5'-UUCUCCGAACGUGUCACGUTT-3'. Target Scan Human 7.2 (www.targetscan.org/vert_72) was used to identify the predicted target of miR-145-5p (17). When the 5637 and T24 cells were grown to $60-70 \%$ confluence, the cells were transfected with 20 or $40 \mathrm{nM}$ miR-145-5p mimics or $40 \mathrm{nM}$ inhibitors using Lipofectamine ${ }^{\mathrm{TM}} 2000$ transfection reagent (Invitrogen; Thermo Fisher Scientific, Inc.) and Opti-MEM medium (Gibco; Thermo Fisher Scientific, Inc.) according to the manufacturer's protocol. A total of $6 \mathrm{~h}$ following transfection, the medium was replaced with fresh medium containing $10 \%$ FBS. Cells were then incubated for $48 \mathrm{~h}$ at $37^{\circ} \mathrm{C}$ in an atmosphere containing $5 \% \mathrm{CO}_{2}$.

RNA extraction and reverse transcription-quantitative polymerase chain reaction ( $R T-q P C R)$ analysis. At $48 \mathrm{~h}$ following transfection or celecoxib treatment, total RNA was extracted from T24 and 5637 cells using TRIzol ${ }^{\circledR}$ reagent (Invitrogen; Thermo Fisher Scientific, Inc.) for $5 \mathrm{~min}$ at room temperature. cDNA was synthesized using a Takara PrimeScript RT reagent kit (Takara Biotechnology Co., Ltd., Dalian, China) according to the manufacturer's protocol and specific miR-145 primers from the Bulge-Loop ${ }^{\mathrm{TM}}$ hsa-miR-145-5p RT-qPCR Primer Set (Guangzhou RiboBio Co., Ltd.) were used for miRNA quantitative analysis. RT-qPCR was performed using a SYBR Premix Ex Taq kit (Takara Bio, Inc., Otsu, Japan) in the ABI PRISM 7500 real-time PCR system (Applied Biosystems; Thermo Fisher Scientific, Inc.) using $400 \mathrm{ng}$ total RNA. PCR reaction conditions were performed as follows: $95^{\circ} \mathrm{C}$ for $2 \mathrm{~min}$, followed by 40 cycles at $95^{\circ} \mathrm{C}$ for $15 \mathrm{sec}, 60^{\circ} \mathrm{C}$ for $30 \mathrm{sec}$ and $72^{\circ} \mathrm{C}$ for $30 \mathrm{sec}$. The RT-qPCR results were normalized against an internal control (U6 for miR-145, GAPDH for mRNA) and the relative expression levels were evaluated using the $2^{-\Delta \Delta C q}$ method (18) and then expressed as the fold change. All reactions were performed at least in triplicate. The oligonucleotide sequences of the RT-qPCR primers are listed in Table I.

Western blot analysis. Total proteins from the 5637 and T24 cells were prepared using RIPA lysis buffer (Beyotime Institute of Biotechnology, Jiangsu, China). Proteins were quantified using a Pierce BCA protein Assay kit (Thermo Fisher Scientific, Inc.), followed by western blot analysis. Proteins from cell lysates $(40 \mu \mathrm{g})$ were subjected to $12 \%$ SDS-PAGE. Once the blots were transferred to a polyvinylidene difluoride membrane, they were blocked for $2 \mathrm{~h}$ in $5 \%$ skimmed milk in Tris-buffered saline with Tween ${ }^{\circledR}-20$ at room temperature. Subsequently, antibodies targeting GAPDH (cat no. ab8245; 1:1,000; Abcam, Cambridge, UK), COX-2 (cat no. 12282; 1:1,000; CST Biological Reagents Co., Ltd., Shanghai, China) Vimentin (cat no. ab32131; 1:500; Abcam), E-cadherin (cat no. 3195; 1:1,000; CST Biological Reagents Co., Ltd.), Smad3 (cat no. 9523; 1:1,000; CST Biological Reagents Co., Ltd.) and TGFBR2 (cat no. 79424; 1:1,000; CST Biological Reagents Co., Ltd.) were used to incubate the membranes overnight at $4^{\circ} \mathrm{C}$, followed by a horseradish peroxidase-labeled goat anti-rabbit secondary antibody (cat no. ab6721; 1:5,000; Abcam; $1.5 \mathrm{~h}$ incubation at room temperature). Protein bands were visualized by enhanced chemiluminescence (cat. no. WBKLS0500; EMD Millipore, Billerica, MA, USA). Image J 1.45 software (National Institutes of Health, Bethesda, MD, USA) was used to perform densitometry analysis of each band.

Cell viability assay. The effects of celecoxib on the viability of 5637 and T24 cells were assessed using a Cell Counting Kit-8 (CCK-8) detection kit (Nanjing Keygen Biotech Co., Ltd., Nanjing, China). Cells in the exponential growth phase were seeded into a 96-well plate at a density of 6,000 cells per well. After $24 \mathrm{~h}$, celecoxib $(0-300 \mu \mathrm{M})$ was added to the medium. The cells were incubated at $37^{\circ} \mathrm{C}$ for $48 \mathrm{~h}$, then CCK- 8 solution was added and the plate was incubated at $37^{\circ} \mathrm{C}$ for $2.5 \mathrm{~h}$. Absorbance was measured at a wavelength of $450 \mathrm{~nm}$ with a TECAN SPARK 10M Microplate Reader (Tecan Group, Ltd., Männedorf, Switzerland). Cell viability was expressed as a percentage of absorbance in the treated wells compared with that of the untreated (control) wells. Each experiment was performed in triplicate and repeated at least three times.

Cell migration and invasion assays. Cell migration was determined using a wound healing assay. Cells of the 5637 and T24 cell lines were treated with celecoxib, transfected with miR-145 mimic or non-target control for $24 \mathrm{~h}$, and then seeded in 6-well plates. A wound $(\sim 300 \mu \mathrm{m})$ was made by scratching the monolayer with a $10 \mu 1$ pipette tip. The wounded monolayer was then washed three times with phosphate buffered saline to remove cell debris and treated with celecoxib for $24 \mathrm{~h}$. Subsequent to scratching, the area of the cell-free scratch was photographed using a Olympus CKX41 inverse light microscope (Olympus Corporation, Tokyo, Japan) at 0 and $24 \mathrm{~h}$. Cell invasion capacities were measured using a 
Table I. Oligonucleotide sequences for reverse transcription and polymerase chain reaction amplification.

\begin{tabular}{lll}
\hline Gene & \multicolumn{1}{c}{ Sequence (5'-3') } & \\
\hline $\begin{array}{l}\text { Vimentin } \\
\text { E-cadherin }\end{array}$ & F: ACCGCACACAGCAAGGCGAT & R: CGATTGAGGGCTCCTAGCGGTT \\
$\begin{array}{l}\text { Transforming growth } \\
\text { factor } \beta \text { receptor } 2\end{array}$ & F: CTAACCTGCTGCCTGTGTGA & R: GTGTATGTGGCAATGCGTTCTC \\
$\begin{array}{l}\text { SMAD family } \\
\text { member } 3\end{array}$ & F: CCATCTCCTACTACGAGCTGAA & R: TCTGGAGCCATGTATCTTGC \\
$\begin{array}{l}\text { GAPDH } \\
\text { microRNA-145 }\end{array}$ & F: CATGAGAAGTATGACAACAGCCT & R: CACTGCTGCATTCCTGTTGAC \\
& FT GTCCAGTTTTCCCAGG & R: AGTCCTTCCACGATACCAAAGT \\
C6 & CGCACTGGATACGACAGAACAGT & R: GAGCAGGCTGGAGAA \\
& F: CGCAAGGATGACACG & \\
& RT primer: CGCTTCACGAATTTGCGTGTCAT & R: GAGCAGGCTGGAGAA
\end{tabular}

F, forward; R, reverse; RT, reverse transcription.
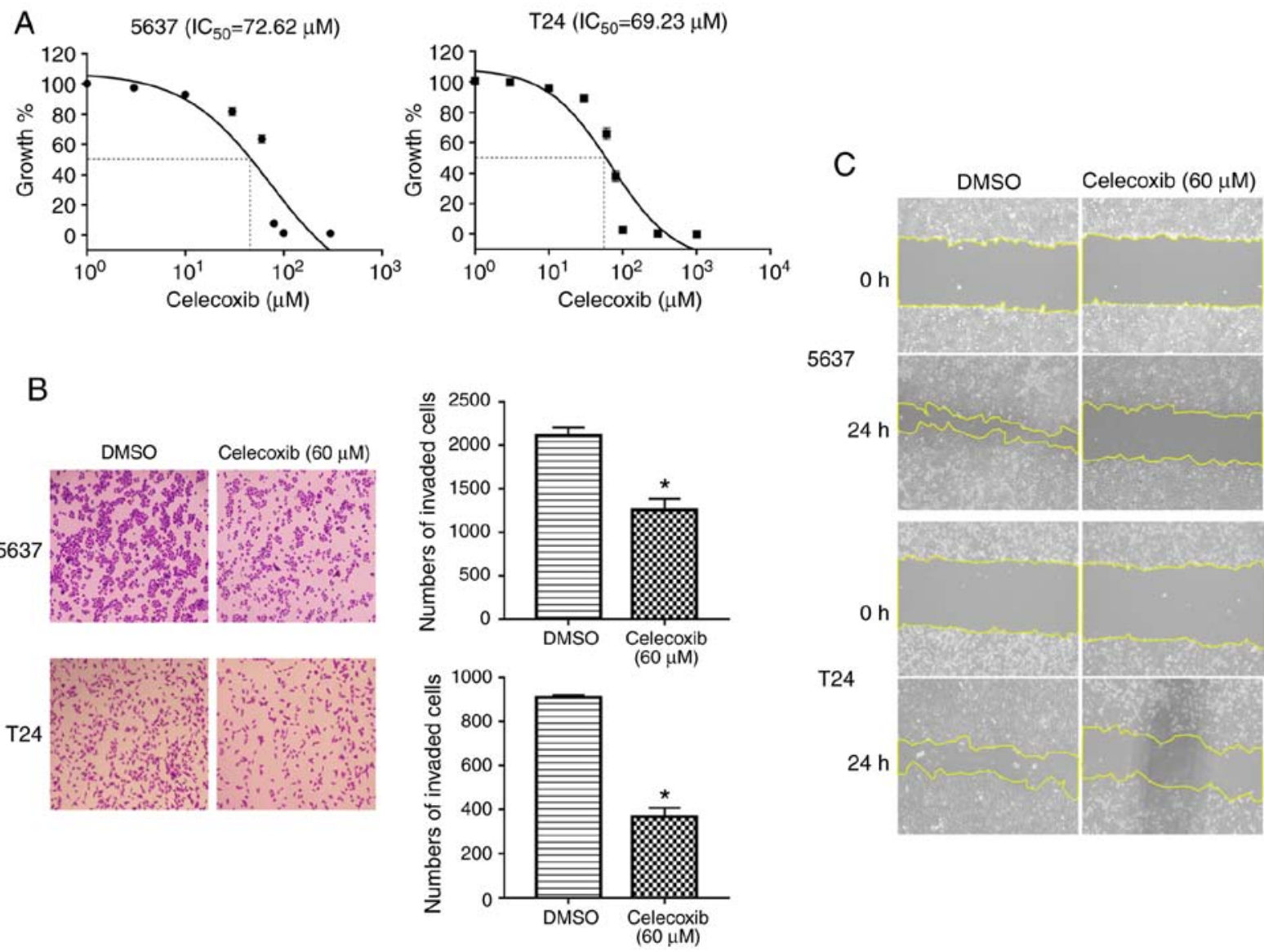

Figure 1. Celecoxib inhibits the viability, migration and invasion of bladder cancer cells. 5637 and T24 bladder cancer cells were treated with celecoxib at $0-300$ or $60 \mu \mathrm{M}$. (A) The cell viability of 5637 and T24 cells was decreased by celecoxib treatment in a concentration dependent manner. Invasion and migration were detected by (B) Transwell assays and (C) wound healing assays, respectively (magnification, $\mathrm{x} 100$ ). ${ }^{*} \mathrm{P}<0.05$ vs. the DMSO group. DMSO, dimethyl sulfoxide; $\mathrm{IC}_{50}$, half maximal inhibitory concentration.

Transwell assay (Corning Incorporated, Corning, NY, USA). The Transwell assay was performed using a 24-well Transwell chamber (pore size, $8 \mu \mathrm{m}$; Corning Incorporated). Cells of the 5637 and T24 cell lines were treated with celecoxib and/or transfected with miR-145 inhibitor, mimic or negative control for $24 \mathrm{~h}$. Subsequently, a total of $8 \times 10^{4}$ cells/well were seeded in the upper chamber of the Transwell system. The upper chamber of the insert was precoated with $0.1 \mathrm{ml}(300 \mu \mathrm{g} / \mathrm{ml})$ 

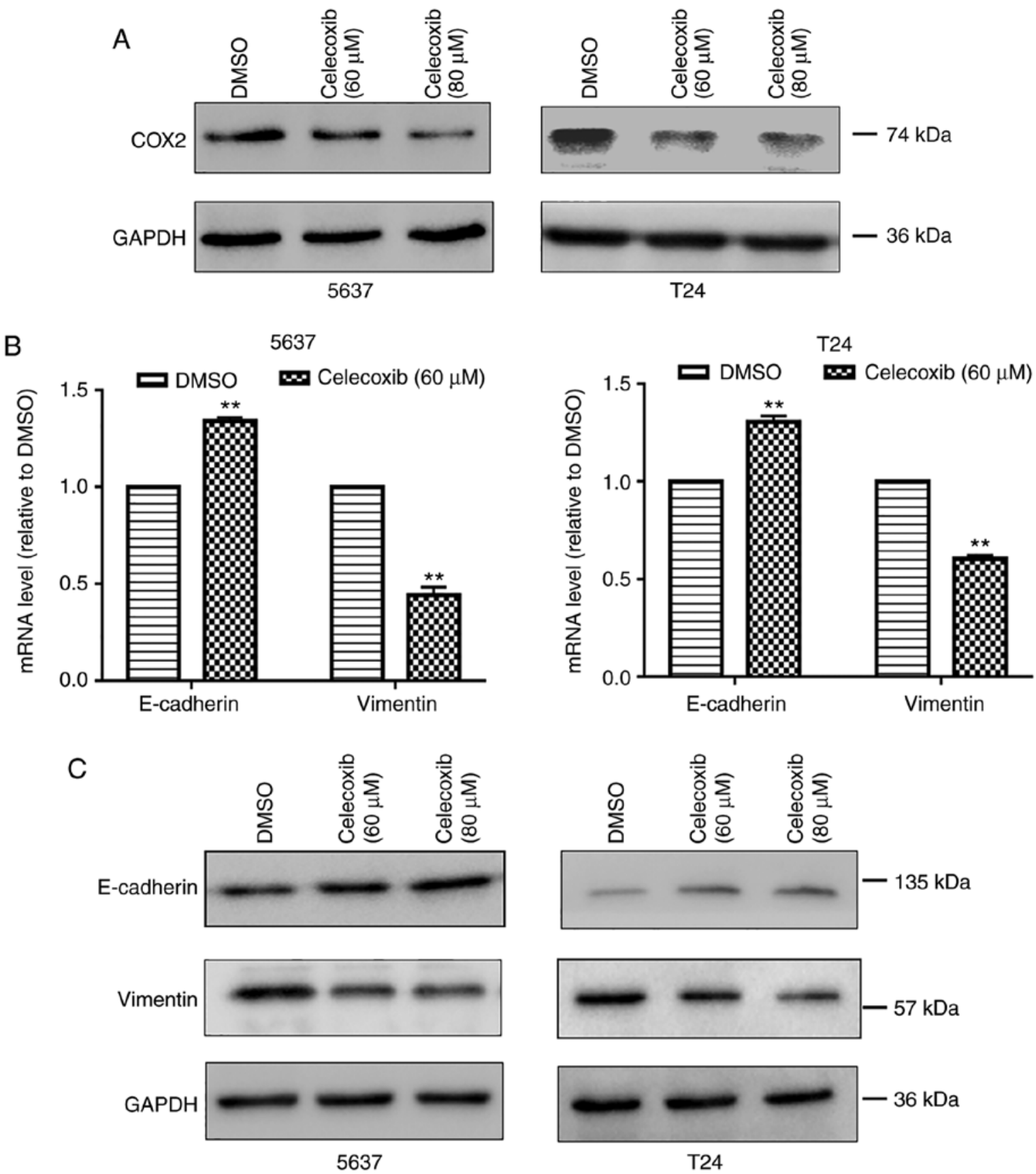

D

5637

T24
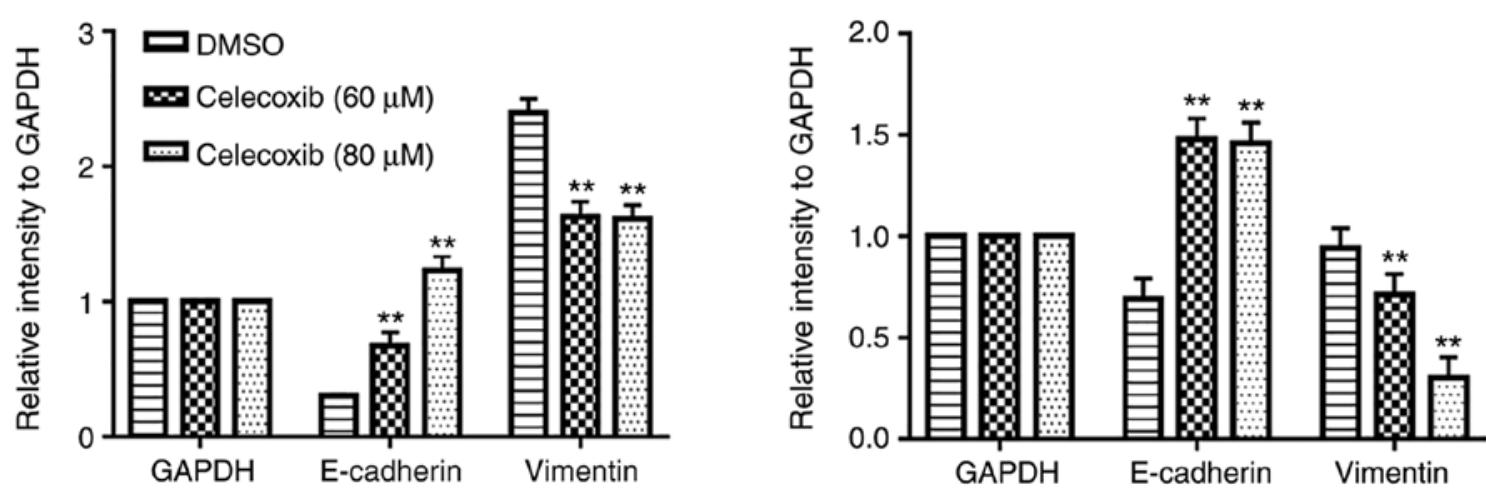

Figure 2. Celecoxib inhibits the epithelial-to-mesenchymal transition and upregulates miR-145 in bladder cancer cells. 5637 and T24 bladder cancer cells were treated with DMSO or celecoxib (60 or $80 \mu \mathrm{M})$ for $48 \mathrm{~h}$. (A) Protein expression of COX-2 in 5637 and T24 cells subsequent to treatment with celecoxib were detected by western blot analysis. GAPDH was used as an internal control. (B) mRNA expression levels of E-cadherin and Vimentin were examined using RT-qPCR. GAPDH was used as an internal control.(C) Protein expression levels of E-cadherin and Vimentin in 5637 and T24 cells were detected by western blot analysis and (D) quantified. GAPDH was used as an internal control. 


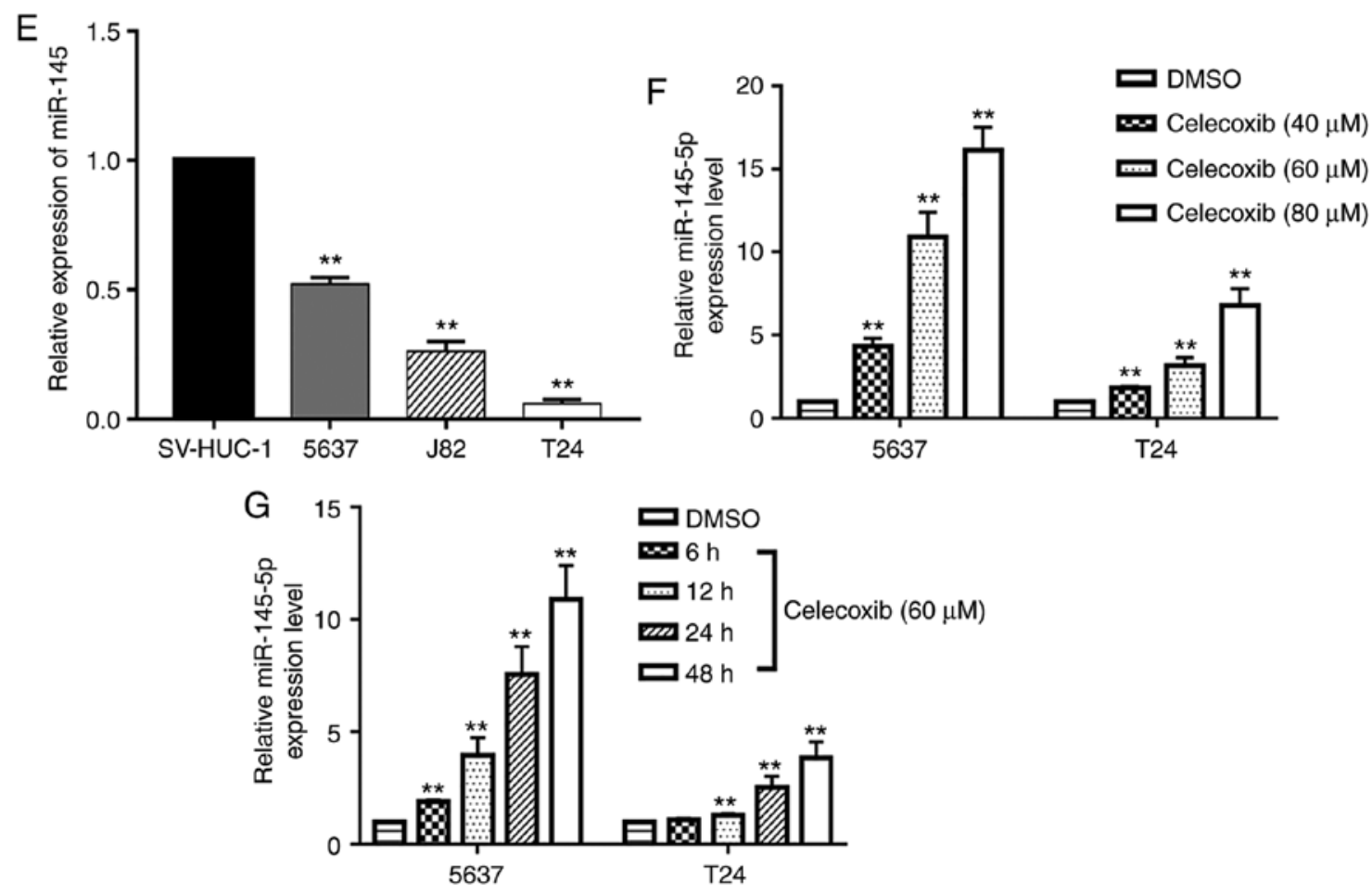

Figure 2. Continued. Celecoxib inhibits the epithelial-to-mesenchymal transition and upregulates miR-145 in bladder cancer cells. (E) Expression levels of miR-145 in bladder cancer cell lines, as detected by RT-qPCR. SV-HUC-1 was used as a normal control. Effect of celecoxib on the expression levels of miR-145 in (F) dose-dependent and (G) time-dependent manners. Expression levels of miR-145 in 5637 and T24 cells following treatment with celecoxib were detected by RT-qPCR. U6 was used as an internal control. The data represent the mean \pm standard deviation of three independent experiments. ${ }^{* *} \mathrm{P}<0.05$ vs. the DMSO group. DMSO, dimethyl sulfoxide; COX2, cyclooxygenase-2; miR, microRNA; RT-qPCR, reverse transcription-quantitative polymerase chain reaction.

Matrigel matrix (Corning Incorporated) for the invasion assay. The invaded cells on the underside of the membrane were then counted. In this assay, prepared cells were seeded in the upper chamber with serum-free RPMI-1640 medium and the medium of the lower chamber was supplemented with $10 \%$ FBS as a chemoattractant. Following incubation for $24 \mathrm{~h}$, the cells were fixed using $4 \%$ formaldehyde at $37^{\circ} \mathrm{C}$ for $30 \mathrm{~min}$. Cells not invading through the pores were removed using a cotton swab. Cells that had invaded to the lower surface of the membrane were stained using crystal violet at room temperature for $15 \mathrm{~min}$. Finally, five representative fields at a magnification of x100 were randomly imaged and quantified for each well using the Olympus CKX41 inverse light microscope.

Statistical analysis. All data are presented as the mean \pm standard deviation in at least three replicates per group. Statistical analysis was performed to determine the significance of the difference between groups using one-way analysis of variance followed by post hoc Turkey's honest significant difference test, or a Student's t test. All statistical analyses were performed using GraphPad Prism 7.00 software (GraphPad Software, Inc., La Jolla, CA, USA) for Windows. $\mathrm{P}<0.05$ was considered to indicate a statistically significant difference.

\section{Results}

Celecoxib inhibits the viability, migration, invasion and EMT of BC cells. To investigate the function of celecoxib in BC cells, two BC cell lines, 5637 and T24, were selected to undertake cell viability, wound healing and Transwell assays. As presented in Fig. 1A, consistent with the results of a previous study, celecoxib inhibits the growth of 5637 and T24 cells (10). Additionally, following stimulation with $60 \mu \mathrm{M}$ celecoxib for $24 \mathrm{~h}$, there were significantly fewer cells invading to the lower surface compared with the control group $(\mathrm{P}<0.05$; Fig. 1B) and less wound healing compared with the control group (Fig. 1C). The present study then evaluated the expression of COX-2 in 5637 and T24 cells following celecoxib treatment. As presented in Fig. 2A, celecoxib downregulated the expression of COX-2. Furthermore, it was detected that the mRNA and protein expression levels of the EMT-associated molecule, E-cadherin, an epithelial marker, significantly increased, whereas the expression levels of the mesenchymal marker, Vimentin, significantly decreased in 5637 and T24 cells following $24 \mathrm{~h}$ treatment with 60 or $80 \mu \mathrm{M}$ celecoxib compared with the control group $(\mathrm{P}<0.05$; Fig. 2B-D). Hence, the results of the present study indicated that celecoxib inhibits the proliferation, migration, invasion and EMT of BC cells.

miR-145 increases with celecoxib treatment in BC cells. EMT is thought to serve a key function in the invasion and metastasis of numerous tumor types (19). A body of literature has revealed that miRNAs have been implicated in the regulation of a variety of cellular functions and biological alterations including EMT (20-22). miR-145 is a regulator of EMT in numerous cancer types (23-26) including BC (27). It was revealed, in the present study, that the relative expression levels of miR-145 were significantly downregulated in $\mathrm{BC}$ cells compared with the control cells $(\mathrm{P}<0.05$; Fig. $2 \mathrm{E})$. Additionally, the levels of miR-145 in 5637 cells were higher 


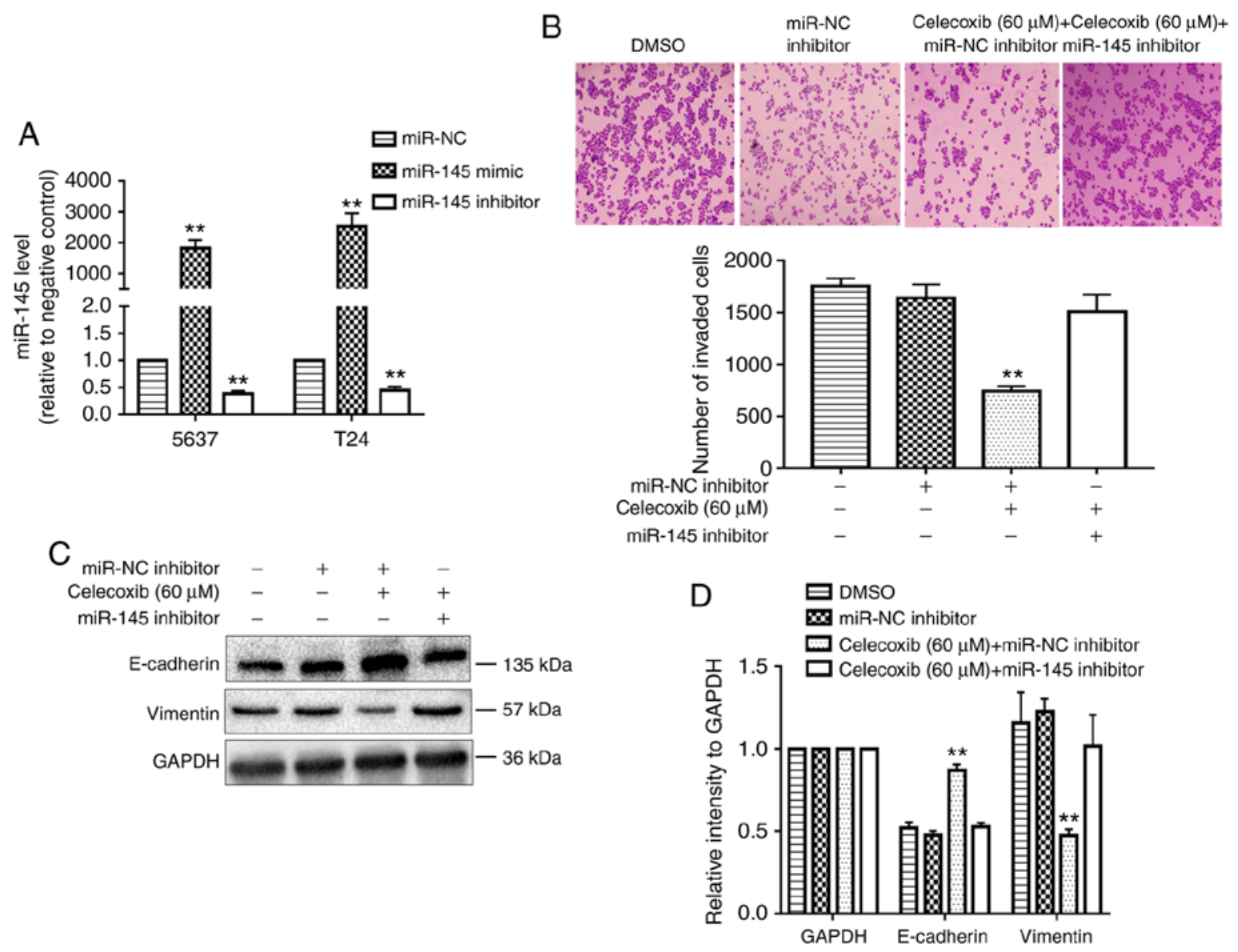

Figure 3. miR-145 is required for the celecoxib-mediated inhibition of EMT. (A) Quantified results from reverse transcription-quantitative polymerase chain reaction analysis following the transfection of 5637 and T24 cells with miR-145 mimics and inhibitors. (B) Celecoxib inhibited the invasion of 5637 cells, while miR-145 inhibitor treatment rescued the effect. (C) Alteration of the expression levels of the EMT-associated markers E-cadherin and Vimentin, caused by celecoxib $(60 \mu \mathrm{M})$ treatment, were rescued by transfection with the miR-145 inhibitor. (D) Statistical analysis of $(\mathrm{C}) .{ }^{* *} \mathrm{P}<0.05 \mathrm{vs}$. miR-NC or the celecoxib $(60 \mu \mathrm{M})+$ miR-145 inhibitor group. miR, microRNA; EMT, epithelial-to-mesenchymal transition; NC, negative control; DMSO, dimethyl sulfoxide.
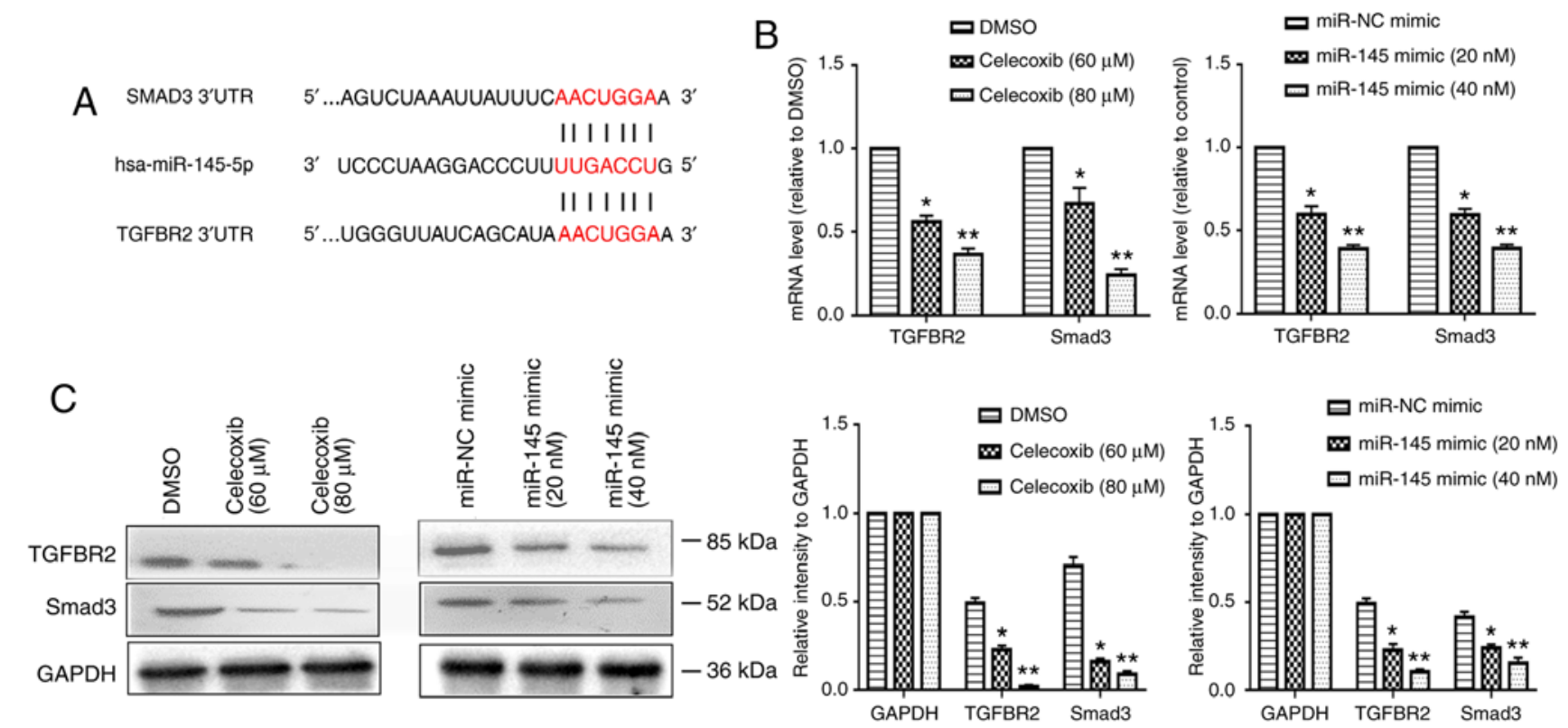

Figure 4. TGFBR2/Smad3 is the direct target of miR-145. (A) TGFBR2 and Smad3 was identified as downstream targets of miR-145. (B) T24 cells were treated with celecoxib $(60$ or $80 \mu \mathrm{M})$ or transfected with miR-145 mimic $(20$ or $40 \mathrm{nM})$ for $24 \mathrm{~h}$, and the expression levels of TGFBR2 and Smad 3 were examined using a reverse transcription-quantitative polymerase chain reaction. GAPDH was used as an internal control. (C) Protein expression levels of TGFBR2 and Smad3 in T24 cells were detected using western blot analysis. GAPDH was used as an internal control. ${ }^{*} \mathrm{P}<0.05$ vs. the DMSO or miR-NC mimic group. ${ }^{* * *} \mathrm{P}<0.05$ vs. DMSO and celecoxib $(60 \mu \mathrm{M})$ or miR-NC mimic and miR-145 mimic (20 nM) group. Smad3, SMAD family member 3; miR, microRNA; TGFBR2, transforming growth factor $\beta$ receptor 2; DMSO, dimethyl sulfoxide; NC, negative control. 
A
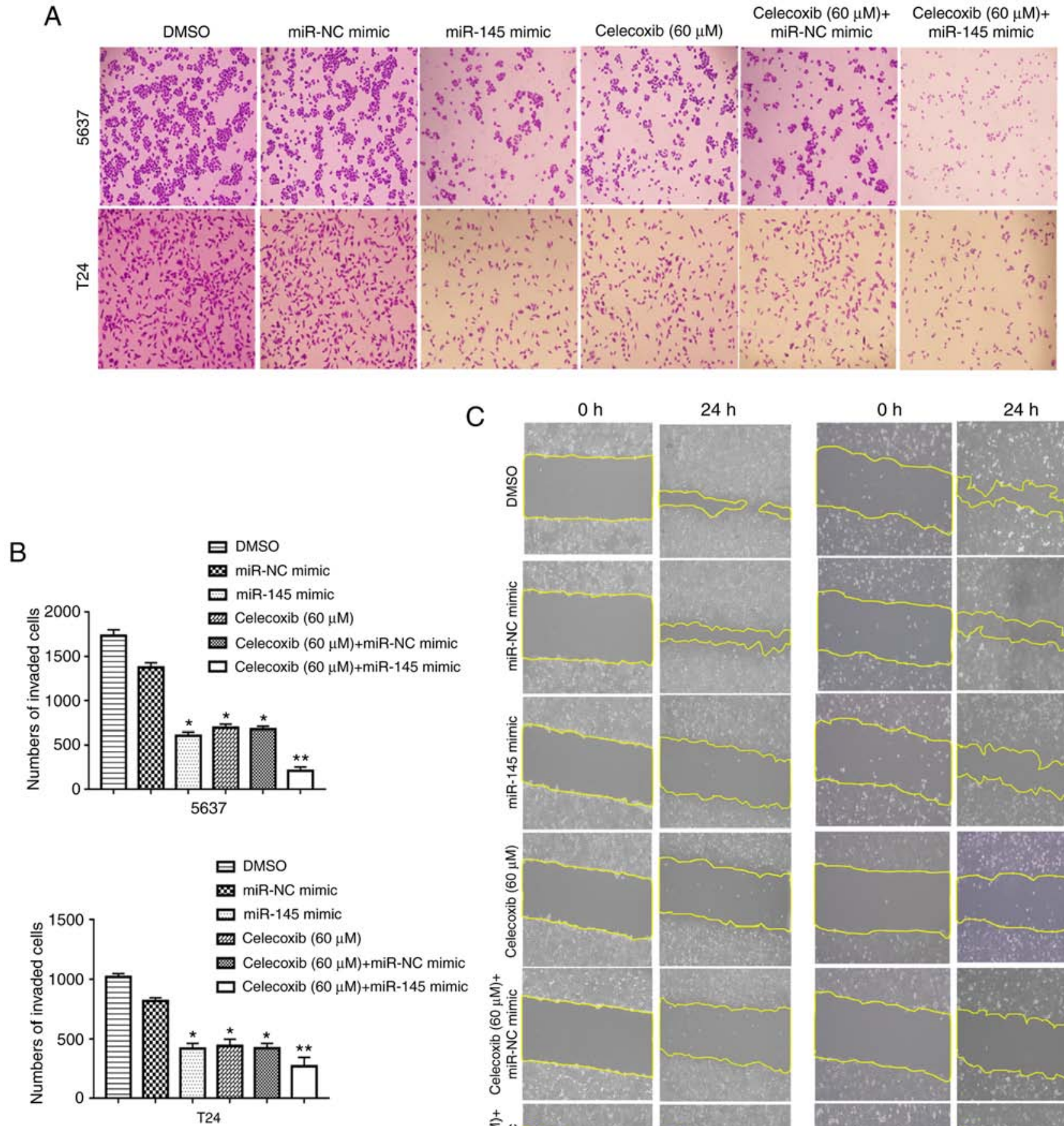

C

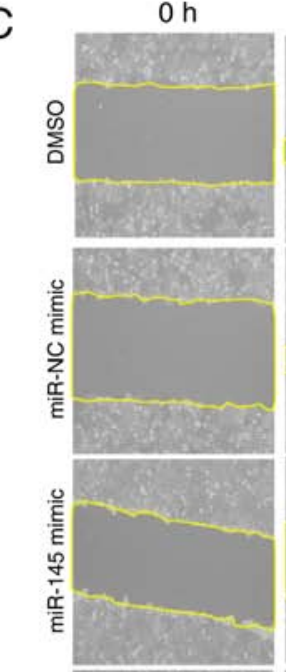

$24 \mathrm{~h}$
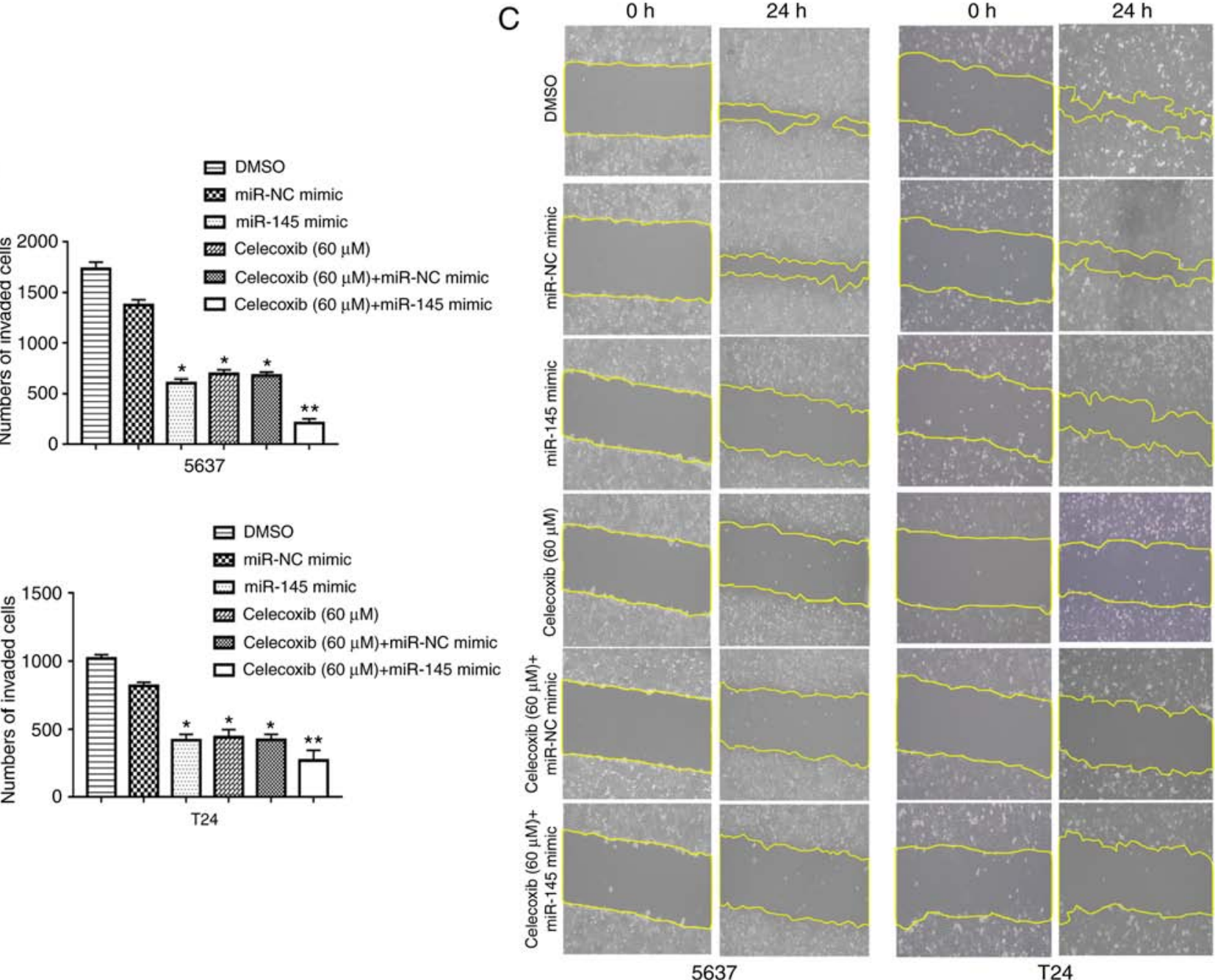

Figure 5. Migration and invasion inhibition of bladder cancer cells by the combined treatment of celecoxib and miR-145 mimic. The 5637 and T24 cells were treated with celecoxib $(60 \mu \mathrm{M})$ at $24 \mathrm{~h}$ following transfection with or without miR-NC mimic or miR-145 mimic $(20 \mathrm{nM})$. Migration and invasion of 5637 and T24 cells following the combined treatment of celecoxib and miR-145 mimic were detected by (A) Transwell assays which were (B) quantified and (C) wound healing assays, respectively (magnification $\mathrm{x} 100$ ). ${ }^{*} \mathrm{P}<0.05$ vs. the DMSO and miR-NC mimic group. ${ }^{* *} \mathrm{P}<0.05$ vs. all other groups. miR, microRNA; NC, negative control; DMSO, dimethyl sulfoxide.

compared with T24 cells. Notably, the expression of endogenous E-cadherin in 5637 cells has also been demonstrated to be greater compared with T24 cells (28-30). These results suggest that miR-145 may be a suppressor of EMT in BC cells. To investigate the molecular mechanism by which celecoxib reverses EMT in BC cells, the present study examined the levels of miR-145 in BC cells following treatment with celecoxib. Interestingly, as presented in Fig. 2F-G, celecoxib significantly increased the expression of miR-145 in 5637 and T24 cells in a time- and dose-dependent manners $(\mathrm{P}<0.05)$. This suggests that celecoxib may directly affect the transcriptional expression of miR-145, and not merely select 


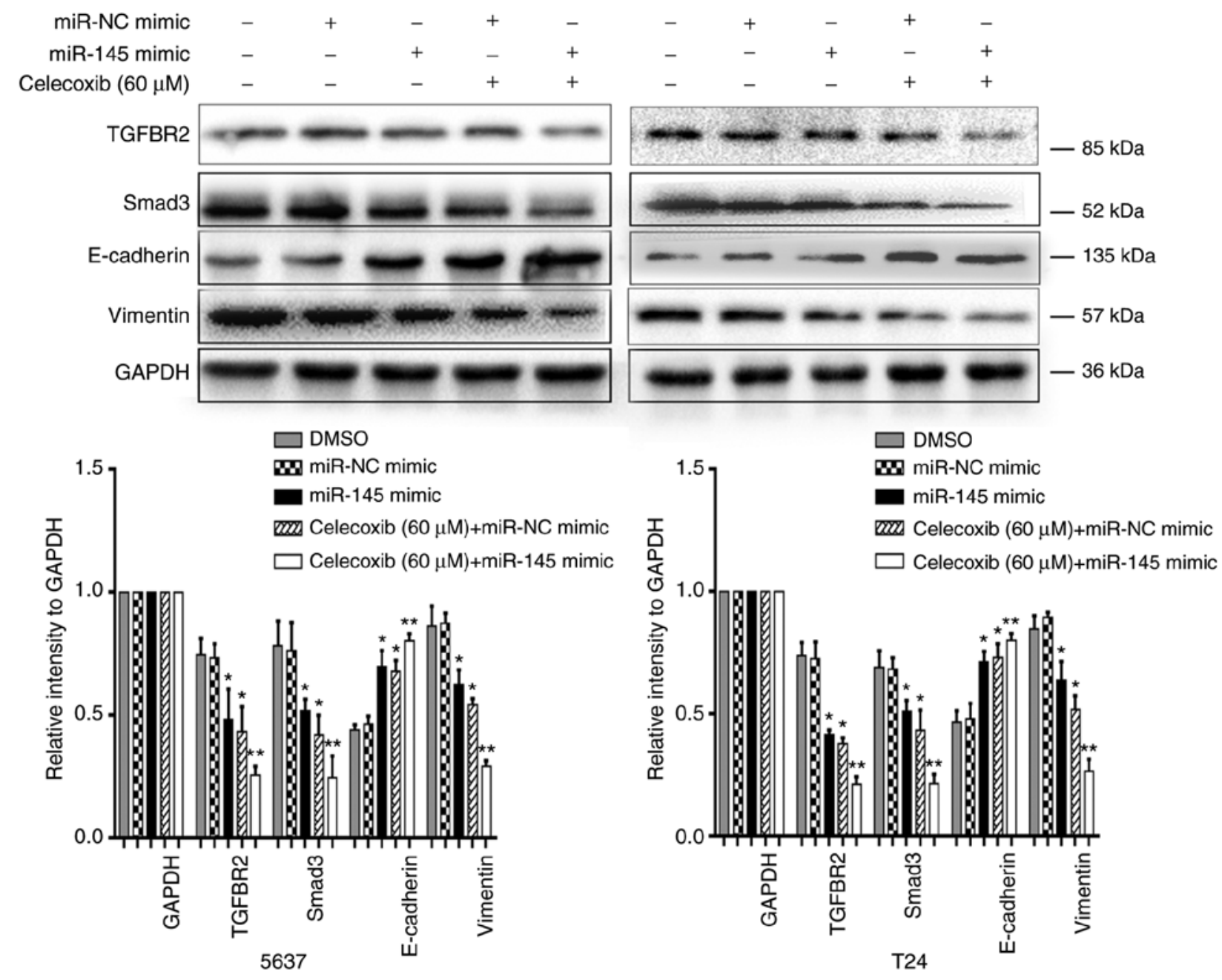

Figure 6. Expression of epithelial-to-mesenchymal transition markers and miR-145 targeted proteins in bladder cancer cells at $48 \mathrm{~h}$ following transfection with miR-145 mimic $(20 \mathrm{nM})$ or miR-NC mimic and treatment with celecoxib $(60 \mu \mathrm{M})$ for $24 \mathrm{~h}$, as assessed by western blot analysis. ${ }^{*} \mathrm{P}<0.05 \mathrm{vs}$. the DMSO and miR-NC mimic group. ${ }^{* *} \mathrm{P}<0.05$ vs. all other groups. miR, microRNA; NC, negative control; DMSO, dimethyl sulfoxide; TGFBR2, transforming growth factor $\beta$ receptor 2; Smad3, SMAD family member 3 .

for resistant populations that are inherently E-cadherin and miR-145 positive.

miR-145 is required for the celecoxib-mediated inhibition of EMT. Initially, the effect of the transfection of miR-145 mimics and inhibitors in 5637 and T24 cells were confirmed using RT-qPCR (Fig. 3A). The present study then determined whether miR-145 was required for the celecoxib-mediated inhibition of EMT. The administration of celecoxib significantly inhibited the invasion ability of miR-NC inhibitor-transfected 5637 cells compared with the negative control group $(\mathrm{P}<0.05)$ but not the miR-145 inhibitor-transfected 5637 cells (Fig. 3B). In addition, the protein levels of E-cadherin were reduced and the Vimentin levels were increased in miR-145 inhibitor-transfected 5637 cells compared with the miR-NC inhibitor-transfected 5637 cells following the administration of celecoxib (Fig. 3C and D).

TGFBR2/Smad3 is the direct target of miR-145. Tumor growth factor $\beta$ (TGF- $\beta$ ) signaling have emerged as major inducers of EMT, particularly the TGF- $\beta$-induced Smad signaling pathway (31-34). miR-145 has been reported to affect TGF- $\beta$-induced EMT by directly targeting Smad3 and TGFBR2 $(24,35,36)$. It was hypothesized that this may be the mechanism by which miR-145 mediates the inhibition of EMT induced by celecoxib. The putative targets of miR-145 were predicted by using the TargetScanHuman 7.2 website, and Smad 3 and TGFBR 2 were identified (Fig. 4A). In addition, the mRNA and protein levels of Smad3 and TGFBR2 in T24 cells were all significantly reduced following the administration of celecoxib and miR-145 overexpression ( $\mathrm{P}<0.05$; Fig. $4 \mathrm{~B}$ and $\mathrm{C}$ ).

Celecoxib in combination with miR-145 mimic revealed an additive EMT-suppressing effect. A previous study demonstrated that celecoxib has potent anti-tumor effects in combination with BCG immunotherapy in an experimental model of murine BC (11). Another previous study revealed that the intravesical administration of exogenous miR-145 may inhibit tumor growth in mouse orthotopic human BC xenografts (37). However, to the best of our knowledge, no studies have previously reported the effect of the combination of celecoxib and miR-145 on BC. To understand the efficacy of the combined treatment of celecoxib and miR-145 mimic, the invasion and migration inhibitory effects of the combined 
treatment of celecoxib and miR-145 mimic on human BC were examined in vitro. The data indicated that celecoxib in addition to miR-145 mimics (20 nM) exhibited a significantly stronger anti-invasion and anti-migration ability compared with celecoxib alone ( $\mathrm{P}<0.05$; Fig. 5). Additionally, the expression levels of EMT associated proteins and miR-145 targeted proteins were measured using a western blot assay. The results indicated that celecoxib in combination with miR-145 mimic resulted in a significant increase in E-cadherin expression levels compared with celecoxib or miR-145 mimic alone ( $\mathrm{P}<0.05$; Fig. 6). In contrast, celecoxib and miR-145 mimic in combination resulted in a significant decrease in the expression levels of Vimentin, TGFBR2 and Smad3 compared with celecoxib or miR-145 mimic alone $(\mathrm{P}<0.05$; Fig. 6$)$.

\section{Discussion}

EMT is a basic process in the morphogenesis of various tissues during embryonic development, where cells of epithelial lineage lose epithelial traits, undergo a conversion to a mesenchymal lineage and exhibit reduced intercellular adhesion and increased cell motility (31). EMT is thought to serve a key function in carcinogenesis and confers metastatic properties by enhancing the mobility and invasion of cancer cells (19). EMT is also associated with the generation of cancer stem cells, which are closely associated with tumor chemoresistance and recurrence (38). Celecoxib is a type of nonsteroidal anti-inflammatory drug which is a specific inhibitor of COX-2. One previous study has suggested that celecoxib may inhibit EMT in human BC cell lines (10). Additionally, the administration of celecoxib may effectively abolish a COX2-mediated wound response gene signature, and diminish the progressive manifestation of chemoresistance in xenograft tumor types (39). In the present study it was demonstrated that treatment with celecoxib inhibits the invasion, migration (Fig. 1B and C) and EMT (Fig. 2B-D) of BC cells by increasing the expression of $\mathrm{miR}-145$, which has been revealed to influence EMT in numerous tumor types through the direct regulation of a number of genes, including Smad3, N-cadherin and zinc finger E-box binding homeobox $2(23,25,36)$.

miR-145 is a tumor suppressor which is located at the $5 \mathrm{p} 32$ chromosomal region, and its expression is controlled by $\mathrm{p} 53$ and CCAAT/enhancer-binding protein $\beta$ through the protein kinase B pathway (40). Additionally, it has been revealed to be downregulated in numerous cancer types, including gastric cancer (41), colorectal cancer (42), lung cancer (43), prostate cancer (44) and $\mathrm{BC}$ (45). Of note, decreased levels of miR-145 predicted poor prognosis in patients with BC (46). As a suppressor miRNA in BC, miR-145 has crucial functions in tumor initiation (47), growth (48), invasion (49), differentiation (50) and EMT (27). In the present study, it was revealed that celecoxib upregulates the levels of miR-145 in 5637 and T24 BC cells (Fig. 2F-G). The present study further investigated whether miR-145 mediated the EMT-inhibitory effect of celecoxib in BC. As presented in Fig. 3A, miR-145 inhibitor abrogates the inhibitory effect of celecoxib on the invasion and EMT phenotype of 5637 BC cells, suggesting that miR-145 is a mediator of celecoxib in inhibiting the EMT of BC cells. TGF- $\beta$-induced Smad signaling pathways have emerged as major inducers of EMT (31-34). miR-145 has been reported to affect TGF- $\beta$-induced EMT by directly targeting Smad 3 and TGFBR2 $(24,35,36)$. It was hypothesized that celecoxib inhibits EMT through increasing the expression of miR-145 and downregulating Smad3 and TGFBR2 expression. Celecoxib and miR-145 mimic decreased the expression of TGFBR2 and Smad3 mRNA and protein levels compared with the control groups (Fig. 4B and C). However, the potential mechanisms on how celecoxib regulates the expression of miR-145 are unknown. P53 has been identified to positively regulate miR-145 maturation (51). Celecoxib was reported to upregulate the expression of p53 in various cancer cell lines (52-54). Additionally, c-Myb was demonstrated to regulate the transcriptional activation of miR-143/145 in vascular smooth muscle cells (55). Previously, Haldar et al (56) reported that the perioperative inhibition of $\beta$-adrenergic and COX 2 signaling in a clinical trial in patients with breast cancer improves the transcriptome of peripheral blood mononuclear cells (PBMCs) and increases the activity of c-Myb in PBMCs. These results suggest that celecoxib may regulate the expression of miR-145 through p53 and c-Myb.

Previously, Dovedi et al (11) demonstrated that celecoxib has potent anti-tumor effects in combination with BCG immunotherapy in an experimental model of murine BC. Furthermore, the intravesical administration of exogenous miR-145 may inhibit tumor growth in mouse orthotopic human BC xenografts (37). The present study revealed the additive invasion-suppressing effect following the co-treatment of T24 and 5637 cells with celecoxib and miR-145 mimic (Figs. 5 and 6). Li et al (57) reported that miR-145 protects cardiomyocytes against hydrogen peroxide $\left(\mathrm{H}_{2} \mathrm{O}_{2}\right)$-induced apoptosis through targeting the reactive oxygen species (ROS)-activated mitochondrial apoptotic pathway. However, ROS have been identified to mediate p53/p65/miR-145 expressions in alloxan-diabetic rats (58). In urothelial carcinoma cell lines, the ectopic expression of miR-145 induced apoptosis characterized by caspase activation (59). In the present study, it was demonstrated that miR-145 combined with celecoxib exerted a potent invasion-suppressing effect but was not able to counteract the effect of celecoxib (Figs. 5 and 6). This contradiction may be partly explained by the functional, structural and metabolic differences between mitochondria in malignant and normal cells. Unlike cardiac myocytes, the majority of cancer cells are far less sensitive to the toxicity of ROS (60).

In conclusion, the present study demonstrated that celecoxib inhibits migration, invasion and EMT partly via the miRNA-145/TGFBR2/Smad3 axis in BC cells. Co-treatment with celecoxib and miR-145 exerted an additive anti-tumor effect by negatively regulating TGF- $\beta$ signaling pathways in human BC cells, as presented in Figs. 5 and 6. In a future study, the restoration of miR-145 and an effective drug co-delivery system of celecoxib and miR-145 may be a promising novel approach in BC therapy.

\section{Acknowledgements}

Not applicable.

\section{Funding}

The present study was supported by the National Natural Science Foundation of China (grant no. 81560419), the Natural Science 
Foundation of Jiangxi (grant no. 20151BAB205047) and the Jiangxi Province Infrastructure Facilities for Scientific Research Institutes (grant nos. 20142BBA13038 and 20151BBA13047).

\section{Availability of data and materials}

Data sharing is not applicable to this article, as no datasets were generated or analyzed during the current study.

\section{Authors' contributions}

$\mathrm{XL}, \mathrm{YWu}, \mathrm{ZZ}$ and $\mathrm{MH}$ performed the experiments and generated data. XL, WD, YWa, XZ, LC and YL analyzed the data. TZ, GW and BF designed the experiments. XL and BF wrote the manuscript. All authors reviewed and approved the manuscript.

\section{Ethics approval and consent to participate}

The present study was approved by the Research Ethics Committee of the First Affiliated Hospital, Nanchang University (Nanchang, China).

\section{Patient consent for publication}

Not applicable.

\section{Competing interests}

The authors declare that they have no competing interests.

\section{References}

1. Parkin DM, Pisani P and Ferlay J: Global cancer statistics. CA Cancer J Clin 49: 33-64, 1, 1999.

2. Siegel RL, Miller KD and Jemal A: Cancer statistics, 2018. CA Cancer J Clin 68: 7-30, 2018

3. Brausi M, Witjes JA, Lamm D, Persad R, Palou J, Colombel M, Buckley R, Soloway M, Akaza $\mathrm{H}$ and Böhle A: A review of current guidelines and best practice recommendations for the management of nonmuscle invasive bladder cancer by the international bladder cancer group. J Urol 186: 2158-2167, 2011.

4. Burger M, Catto JWF, Dalbagni G, Grossman HB, Herr H, Karakiewicz P, Kassouf W, Kiemeney LA, La Vecchia C, Shariat S and Lotan Y: Epidemiology and risk factors of urothelial bladder cancer. Eur Urol 63: 234-241, 2013.

5. Prasad SM, Decastro GJ, Steinberg GD and Medscape: Urothelial carcinoma of the bladder: Definition, treatment and future efforts. Nat Rev Urol 8: 631-642, 2011.

6. Gontero P, Bohle A, Malmstrom PU, O'Donnell MA, Oderda M, Sylvester R and Witjes F: The role of bacillus calmette-guérin in the treatment of non-muscle-invasive bladder cancer. Eur Urol 57: 410-429, 2010.

7. Shariat SF, Kim J-H, Ayala GE, Kho K, Wheeler TM and Lerner SP Cyclooxygenase-2 is highly expressed in carcinoma in situ and $\mathrm{T} 1$ transitional cell carcinoma of the bladder. J Urol 169: 938-942, 2003

8. Ristimäki A, Nieminen O, Saukkonen K, Hotakainen K, Nordling S and Haglund C: Expression of cyclooxygenase- 2 in human transitional cell carcinoma of the urinary bladder. Am J Pathol 158: 849-853, 2001.

9. Gee J, Lee IL, Jendiroba D, Fischer SM, Grossman HB and Sabichi AL: Selective cyclooxygenase-2 inhibitors inhibit growth and induce apoptosis of bladder cancer. Oncol Rep 15: 471-477, 2006.

10. Adhim Z, Matsuoka T, Bito T, Shigemura K, Lee KM, Kawabata M, Fujisawa M, Nibu K and Shirakawa T: In vitro and in vivo inhibitory effect of three Cox-2 inhibitors and epithelial-to-mesenchymal transition in human bladder cancer cell lines. Br J Cancer 105: 393-402, 2011.
11. Dovedi SJ, Kirby JA, Davies BR, Leung H and Kelly JD: Celecoxib has potent antitumour effects as a single agent and in combination with BCG immunotherapy in a model of urothelial cell carcinoma. Eur Urol 54: 621-630, 2008.

12. Bartel DP: MicroRNAs: Genomics, biogenesis, mechanism, and function. Cell 116: 281-297, 2004.

13. Gebert LFR and MacRae IJ: Regulation of microRNA function in animals. Nat Rev Mol Cell Biol 20: 21-37, 2019.

14. Gowda R, Kardos G, Sharma A, Singh S and Robertson GP: Nanoparticle-based celecoxib and plumbagin for the synergistic treatment of melanoma. Mol Cancer Ther 16: 440-452, 2016.

15. Gowda R, Sharma A and Robertson GP: Synergistic inhibitory effects of celecoxib and plumbagin on melanoma tumor growth. Cancer Lett 385: 243-250, 2017.

16. Singh S: Liposome encapsulation of doxorubicin and celecoxib in combination inhibits progression of human skin cancer cells. Int J Nanomedicine 13: 11-13, 2018.

17. Agarwal V, Bell GW, Nam JW and Bartel DP: Predicting effective microRNA target sites in mammalian mRNAs. Elife 4, 2015.

18. Livak KJ and Schmittgen TD: Analysis of relative gene expression data using real-time quantitative PCR and the 2(-Delta Delta C(T)) method. Methods 25: 402-408, 2001.

19. Mittal V: Epithelial mesenchymal transition in tumor metastasis. Annu Rev Pathol Mech Dis 13: 395-412, 2018.

20. Suzuki HI: MicroRNA control of TGF- $\beta$ signaling. Int J Mol Sci 19: pii: E1901, 2018.

21. Expósito-Villén A, E Aránega A and Franco D: Functional role of non-coding RNAs during epithelial-to-mesenchymal transition. Noncoding RNA 4: pii: E14, 2018.

22. Falzone L, Candido S, Salemi R, Basile MS, Scalisi A, McCubrey JA, Torino F, Signorelli SS, Montella M and Libra M: Computational identification of microRNAs associated to both epithelial to mesenchymal transition and NGAL/MMP-9 pathways in bladder cancer. Oncotarget 8: 72758-72766, 2016.

23. Ren D, Wang M, Guo W, Huang S, Wang Z, Zhao X, Du H, Song $L$ and Peng X: Double-negative feedback loop between ZEB2 and miR-145 regulates epithelial-mesenchymal transition and stem cell properties in prostate cancer cells. Cell Tissue Res 358: 763-778, 2014.

24. Hu H, Xu Z, Li C, Xu C, Lei Z, Zhang HT and Zhao J: miR-145 and miR-203 represses TGF- $\beta$-induced epithelial-mesenchymal transition and invasion by inhibiting SMAD3 in non-small cell lung cancer cells. Lung Cancer 97: 87-94, 2016.

25. Jiang S Bin, He XJ, Xia YJ, Hu WJ, Luo JG, Zhang J and Tao HQ: MicroRNA-145-5p inhibits gastric cancer invasiveness through targeting N-cadherin and ZEB2 to suppress epithelial-mesenchymal transition. Onco Targets Ther 9: 2305-2315, 2016.

26. Chang Y, Yan W, Sun C, Liu Q, Wang J and Wang M: miR-145-5p inhibits epithelial-mesenchymal transition via the JNK signaling pathway by targeting MAP3K1 in non-small cell lung cancer cells. Oncol Lett 14: 6923-6928, 2017.

27. Tan J, Qiu K, Li M and Liang Y: Double-negative feedback loop between long non-coding RNA TUG1 and miR-145 promotes epithelial to mesenchymal transition and radioresistance in human bladder cancer cells. FEBS Lett 589: 3175-3181, 2015.

28. Davies G, Jiang WG and Mason MD: Cell-cell adhesion molecules and their associated proteins in bladder cancer cells and their role in mitogen induced cell-cell dissociation and invasion. Anticancer Res 19: 547-552, 1999.

29. Mao Q, Li Y, Zheng X, Yang K, Shen H, Qin J, Bai Y, Kong D, Jia $X$ and Xie L: Up-regulation of E-cadherin by small activating RNA inhibits cell invasion and migration in 5637 human bladder cancer cells. Biochem Biophys Res Commun 375: 566-570, 2008.

30. Jang TJ, Cha WH and Lee KS: Reciprocal correlation between the expression of cyclooxygenase- 2 and E-cadherin in human bladder transitional cell carcinomas. Virchows Arch 457: 319-328, 2010.

31. Lamouille S, Xu J and Derynck R: Molecular mechanisms of epithelial-mesenchymal transition. Nat Rev Mol Cell Biol 15: 178-196, 2014.

32. Derynck R, Muthusamy BP and Saeteurn KY: Signaling pathway cooperation in TGF- $\beta$-induced epithelial-mesenchymal transition. Curr Opin Cell Biol 31: 56-66, 2014.

33. Song $\mathrm{J}$ and Shi W: The concomitant apoptosis and EMT underlie the fundamental functions of TGF- $\beta$. Acta Biochim Biophys Sin (Shanghai) 50: 91-97, 2018. 
34. Cantelli G, Crosas-Molist E, Georgouli M and Sanz-Moreno V: TGFB-induced transcription in cancer. Semin Cancer Biol 42: 60-69, 2017.

35. Xiang Y, Zhang Y, Tang Y and Li Q: MALAT1 modulates TGF- $\beta 1$-induced endothelial-to-mesenchymal transition through downregulation of miR-145. Cell Physiol Biochem 42: 357-372, 2017.

36. Megiorni F, Cialfi S, Cimino G, De Biase RV, Dominici C, Quattrucci S and Pizzuti A: Elevated levels of miR-145 correlate with SMAD3 down-regulation in cystic fibrosis patients. J Cyst Fibros 12: 797-802, 2013

37. Inamoto $\mathrm{T}$, Taniguchi $\mathrm{K}$, Takahara $\mathrm{K}$, Iwatsuki $\mathrm{A}$, Takai $\mathrm{T}$, Komura K, Yoshikawa Y, Uchimoto T, Saito K, Tanda N, et al: Intravesical administration of exogenous microRNA-145 as a therapy for mouse orthotopic human bladder cancer xenograft. Oncotarget 6: 21628-21635, 2015.

38. Mani SA, Guo W, Liao MJ, Eaton EN, Ayyanan A, Zhou AY, Brooks M, Reinhard F, Zhang CC, Shipitsin M, et al: The epithelial-mesenchymal transition generates cells with properties of stem cells. Cell 133: 704-715, 2008.

39. Kurtova AV, Xiao J, Mo Q, Pazhanisamy S, Krasnow R, Lerner SP, Chen F, Roh TT, Lay E, Ho PL and Chan KS: Blocking PGE2-induced tumour repopulation abrogates bladder cancer chemoresistance. Nature 517: 209-213, 2015.

40. Sachdeva M, Liu Q, Cao J, Lu Z and Mo Y: Negative regulation of miR-145 by C/EBP- $\beta$ through the Akt pathway in cancer cells. Nucleic Acids Res 40: 6683-6692, 2012.

41. Takagi T, Iio A, Nakagawa $\mathrm{Y}$, Naoe T, Tanigawa $\mathrm{N}$ and Akao $\mathrm{Y}$ : Decreased expression of microRNA-143 and-145 in human gastric cancers. Oncology 77: 12-21, 2009.

42. Slaby O, Svoboda M, Fabian P, Smerdova T, Knoflickova D, Bednarikova M, Nenutil R and Vyzula R: Altered expression of miR-21, miR-31, miR-143 and miR-145 is related to clinicopathologic features of colorectal cancer. Oncology 72: 397-402, 2008.

43. Liu X, Sempere LF, Galimberti F, Freemantle SJ, Black C, Dragnev KH, Ma Y, Fiering S, Memoli V, Li H, et al: Uncovering growth-suppressive microrNAs in lung cancer. Clin Cancer Res 15: 1177-1183, 2009.

44. Tong AW, Fulgham P, Jay C, Chen P, Khalil I, Liu S, Senzer N, Eklund AC, Han J and Nemunaitis J: MicroRNA profile analysis of human prostate cancers. Cancer Gene Ther 16: 206-216, 2009.

45. Ichimi T, Enokida H, Okuno Y, Kunimoto R, Chiyomaru T, Kawamoto K, Kawahara K, Toki K, Kawakami K, Nishiyama K, et al: Identification of novel microRNA targets based on microRNA signatures in bladder cancer. Int Cancer 125: 345-352, 2009.

46. Zhuang J, Shen L, Yang L, Huang X, Lu Q, Cui Y, Zheng X, Zhao X, Zhang D, Huang R, et al: TGF $\beta 1$ promotes gemcitabine resistance through regulating the LncRNA-LET/NF90/miR-145 signaling axis in bladder cancer. Theranostics 7: 3053-3067, 2017.

47. Zhu Z, Xu T, Wang L, Wang X, Zhong S, Xu C and Shen Z: MicroRNA-145 directly targets the insulin-like growth factor receptor $\mathrm{i}$ in human bladder cancer cells. FEBS Lett 588 3180-3185, 2014

48. Noguchi S, Yasui Y, Iwasaki J, Kumazaki M, Yamada N, Naito S and Akao Y: Replacement treatment with microRNA-143 and -145 induces synergistic inhibition of the growth of human bladder cancer cells by regulating PI3K/Akt and MAPK signaling pathways. Cancer Lett 328: 353-361, 2013.
49. Kou B, Gao Y, Du C, Shi Q, Xu S, Wang CQ, Wang X, He D and Guo P: miR-145 inhibits invasion of bladder cancer cells by targeting PAK1. Urol Oncol 32: 846-854, 2014.

50. Fujii T, Shimada K, Tatsumi Y, Hatakeyama K, Obayashi C, Fujimoto K and Konishi N: microRNA-145 promotes differentiation in human urothelial carcinoma through down-regulation of syndecan-1. BMC Cancer 15: 818, 2015.

51. Boominathan L: The tumor suppressors p53, p63, and p73 are regulators of microRNA processing complex. PLoS One 5: e10615, 2010

52. Liu HF, Hsiao PW and Chao JI: Celecoxib induces p53-PUMA pathway for apoptosis in human colorectal cancer cells. Chem Biol Interact 176: 48-57, 2008.

53. Piplani H, Vaish V, Rana C and Sanyal SN: Up-regulation of p53 and mitochondrial signaling pathway in apoptosis by a combination of cox- 2 inhibitor, celecoxib and dolastatin 15 , a marine mollusk linear peptide in experimental colon carcinogenesis. Mol Carcinog 52: 845-858, 2013.

54. Gharghabi M, Rezaei F and Mohammadrezaei FM: Celecoxib treatment alters $\mathrm{p} 53$ and $\mathrm{mdm} 2$ expression via COX-2 crosstalk in A549 cells. Iran J Pharm Res 15: 483-489, 2016.

55. Chandy M, Ishida M, Shikatani EA, El-Mounayri O, Park LC, Afroze T, Wang T, Marsden PA and Husain M: c-Myb regulates transcriptional activation of miR-143/145 in vascular smooth muscle cells. PLoS One 13: e0202778, 2018.

56. Haldar R, Shaashua L, Lavon H, Lyons YA, Zmora O, Sharon E, Birnbaum Y, Allweis T, Sood AK, Barshack I, et al: Perioperative inhibition of $\beta$-adrenergic and COX2 signaling in a clinical trial in breast cancer patients improves tumor $\mathrm{Ki}-67$ expression, serum cytokine levels, and PBMCs transcriptome. Brain Behav Immun 73: 294-309, 2018.

57. Li R, Yan G, Li Q, Sun H, Hu Y, Sun J and Xu B: MicroRNA-145 protects cardiomyocytes against hydrogen peroxide $\left(\mathrm{H}_{2} \mathrm{O}_{2}\right)$-induced apoptosis through targeting the mitochondria apoptotic pathway. PLoS One 7: e44907, 2012.

58. Gharib E, Montasser Kouhsari S and Izad M: Punica granatum L. Fruit aqueous extract suppresses reactive oxygen species-mediated $\mathrm{p} 53 / \mathrm{p} 65 / \mathrm{miR}-145$ expressions followed by elevated levels of irs-1 in alloxan-diabetic rats. Cell J 19: 520-527, 2018.

59. Ostenfeld MS, Bramsen JB, Lamy P, Villadsen SB, Fristrup N, Sørensen KD, Ulhøi B, Borre M, Kjems J, Dyrskjøt L and Orntoft TF: miR-145 induces caspase-dependent and -independent cell death in urothelial cancer cell lines with targeting of an expression signature present in Ta bladder tumors. Oncogene 29: 1073-1084, 2010.

60. Javadov S, Hunter JC, Barreto-Torres G and Parodi-Rullan R: Targeting the mitochondrial permeability transition: Cardiac ischemia-reperfusion versus carcinogenesis. Cell Physiol Biochem 27: 179-190, 2011.

This work is licensed under a Creative Commons Attribution-NonCommercial-NoDerivatives 4.0 International (CC BY-NC-ND 4.0) License. 